\title{
ECONOMICS OF CATFISH PRODUCTION IN EKEREMOR LOCAL GOVERNMENT AREA, BAYELSA STATE, NIGERIA
}

\author{
*Godfrey Onuwa ${ }^{1}$, Bassey Emmanuel ${ }^{2}$, Victor Fatoke ${ }^{2}$, Ubana Eshimutu ${ }^{3}$ and Grace Owa ${ }^{1}$ \\ ${ }^{1}$ Department of Agricultural Extension and Management, Federal College of Forestry, Jos, \\ Plateau state, Nigeria. \\ ${ }^{2}$ Montanne Research Station, Forestry Research Institute of Nigeria, Jos, Plateau state, Nigeria. \\ ${ }^{3}$ Northern Guinea Savannah Research Station, Nasarawa state, Nigeria. \\ *Corresponding author: onuwag@gmail.com (08035606473)
}

\begin{abstract}
Catfish farmers are facing new barriers in both their production and returns on investment. Despite its potentials, the level of fish production has failed to meet domestic demand. This study aims to analyze the determinants of catfish production so as to boost the level of farm productivity and profitability. Random sampling techniques were employed in selecting the respondents for this study. Primary data was collected using structured questionnaires. Descriptive statistics, budgetary techniques and multiple regression analysis were the analytical techniques employed. The results indicated that most (58.3\%) were within the age bracket of 20 39 years; $63.3 \%$ were male; most (75\%) used organic fertilizer; $45 \%$ had no access to credit; most $(75 \%)$ had formal education; $83.3 \%$ used earthen ponds; $83.3 \%$ were married; most (58.3\%) had household population of 1-5 people; $66.7 \%$ had farming experience of 1-5 years; $75 \%$ hired labour; $91.7 \%$ had no access to extension contact; $58.3 \%$ had pond size of $1-400$ sqm and most (58.3\%) had stocking density of 1001-2000 fingerlings. The net farm income was $¥ 433,000 / 400$ sqm. Also, the estimated fixed and operating ratios were 0.43 and 0.67 respectively, while the benefit-cost ratio was 1.67. The coefficient of multiple determination $\left(R^{2}\right)$ was 0.839 , hence $84 \%$ variation in the output is attributable to variables included in the regression model. Furthermore, the constraints identified affected catfish production in the study area. However, improved access and supply of feeds, credit, technology, market linkages, extension services, input subsidy, cooperative formation and training are strongly recommended.
\end{abstract}

Keywords: Aquaculture, constraints, determinants, gross output, profitability 


\section{INTRODUCTION}

The aim of fish culture (husbandry) or farming is generally for fish production for human consumption. Fish farming is a technique of hunting from the wild or gathering of natural stocks and confining them into enclosures for production. The term fish is a diverse group of animal that lives and breathe in water by means of gills. Aquaculture or fish farming continues to grow rapidly. Understanding the general aspects of aquaculture is of increasing importance for all those working in this industry. Aquaculture requires specific knowledge and skills on general aspects of fish production (Emokaro, 2010). In the past, rural fish farming in Africa concentrated on tilapia fish productionhowever catfish which is a fast growing fish variety is also on the rise (Olagunjum et al., 2007). Population growth is usually accompanied by increases in the demands for the basic necessities of life including water, food, and shelter. This is the case with the unrestricted increases in the demand for protein rich food items of animal origin (Ugwumba and Chukwuji, 2010). However, the ability of catfish production to reach optimal level has been on the decline, yield (production per unit of water area) for catfish farmers and the profit margins have decreased overtime. The Food and Agriculture Organization (FAO, 1999), recommended that an individual takes $35 \mathrm{~g}$ (grams) of animal protein per day for sustainable growth and development. However, the animal protein consumption in Nigeria is less than $8 \mathrm{~g}$ (grams) per day per person, which is a deficit from the FAO minimum recommendation (Amao, et al., 2009; Okechi, 2004). Fish especially the catfish species are widely consumed in Nigeria. The shortage of the fish protein source in Nigeria may have been responsible for the importation of the product in the country.Currently, domestic fish production is put at 600,000 metric tonnes as against the present national demand of about 1.5 million metric tonnes per annum; over $50 \%$ of fish supply requirement is met through importation, which constitutes a huge and avoidable drain of Nigeria's scarce foreign exchange resources.Hence a demand deficit of 900,000 metric tons per annum in a population growing at an estimated 2.5\% annually (Asa and Obinaju, 2014).The shortfall is said to be bridged by the importation of 700,000 metric tonnes annually for domestic consumption.Increased awareness of the need for adequate protein in human diets, assessment of production determinants and constraints are approaches of improving production so as to achieve self-sufficiency in fish production (Okwu and Acheje, 2011). The government at various occasions have adopted different programmes and policies aimed at raising productivity and efficiency of fish production. These programmes and policies place the small holder producers in central focus, hence,these subsector is particularly dominated by the small holder fish farmers who represent a substantial proportion of the total farming population and contribute to over $80 \%$ of the total output.The major animal protein sources in the country include cattle, goats, sheep, poultry and fish. According to Ocmer (2006) fish and fish products constitute more than $60 \%$ of the total protein intake in adult especially in rural areas. Therefore, the importance of fish farming particularly catfish production, to the sustainability of animal protein supply cannot be overemphasized (FAO, 2006). Fish farming can be a viable venture with proper management.

Smallholder farmers are facing new barriers in both their production and returns on investment.

Despite its potentials, the level of fish production has failed to meet the country domestic demand (Food Agricultural Organization (FAO), 2007). The catfish sub sector remains a viable investment in Nigeria (Oguntola, 2006). The ability of catfish farmers to reach optimal 
production level has been on the decline over the years, despite the efforts of government and other interventions from stakeholders, yield has remained low in the country and particularly in the study area; there is still a deficit in the supply and demand for catfish (Dada, 2004). This has been attributed to inadequate supply of production inputs, poor quality of fingerlings, inadequate extension services, high cost of feeds, poor adoption of improved techniques, prevalence of smallholder fish farmers, poor infrastructural facilities and low capital investment. These factors account for the decline in the fish population dynamics and therefore the need to increase fish production through intensification of aquaculture systems. The contribution of domestic fish farming cannot be over emphasized. Catfish farming has the potential of contributing to domestic fish production and reducing the amount of money spent on fish importation. Hence, this research will fill the gap and provide empirical information on catfish production in Ekeremor Local Government Area (LGA) of Bayelsa State; within this framework this study will seek to provide answers to the following research questions;

1. What are the socioeconomic characteristics of catfish farmers in the study area?

2. What are the cost and returns of catfish production?

3. What are the determinants of yield in catfish production?

4. What are the constraints of catfish production?

\section{Research hypothesis}

$\mathrm{H}_{0}$ : There is no input and output relationship in catfish production.

\section{METHODOLOGY}

\section{Study Area}

The study was carried out in Ekeremor LGA of Bayelsa State, Nigeria. Ekeremor local government is one of the eight local government areas (LGAs) in Bayelsa State. It borders Delta State and has a coastline of approximately $60 \mathrm{~km}$ on the Bight of Bonny. Its headquarters is in the town of Ekeremor in the northeast of the area (en.m.wikipedia.org/wiki/Ekeremor, 2015). It has an area of $1,810 \mathrm{~km}^{2}$ and a population of 270,257 at the 2006 census, it lies on the geographical coordinates of latitude $5^{\circ} 3^{\prime} \mathrm{N}$ and longitude $5^{\circ} 47^{\prime} \mathrm{E}$ (en.m.wikipedia.org/wiki/Ekeremor, 2015). Mean annual rainfall of the area is $2,200 \mathrm{~mm}$ for upland or dry regions where water bodies are few and $3,500 \mathrm{~mm}$ for wetland or lowland regions which comprises of land areas being surrounded by water bodies. Temperature range is between $23-31^{\circ} \mathrm{C}$ and vegetation found in the area include the saline water swamp, Mangrove swamp and the rain forest. Major seasons are the dry (November - February) and wet seasons (October - March). Also, the seasonal condition of the area presents a healthy environment for fish production, hence adequate supply of water for catfish ponds in the study area. Ekeremor LGA is home to members of Ekeremor clan of the Ijaw ethnic group and its inhabitants are predominantly fish farmers.

\section{Sampling Technique}

Random sampling technique was employed in selecting the respondents for this study. A sample size of sixty (60) respondents were randomly selected from a compiled list of catfish farmers 
from Bayelsa state Agricultural Development Programme (BYADEP) with the assistance of extension agents.

\section{Method of Data Collection}

A well-structured questionnaire designed in line with the objectives of the study was used for the collection of data. The data collected for this study were obtained from primary sources. The primary data will be collected for this research through scheduled interviews and observations, using a well-structured questionnaire. A total of 60 questionnaires were administered to the respondents, which were all retrieved and found to be valid enough for further analysis, giving a response rate of $100 \%$.

\section{Analytical Techniques}

The analytical tools adopted for this study were; descriptive statistics (such as percentages, frequency distribution and means) to analyze objectives i and iv. Budgetary techniques such as, farm budgeting tools (gross margin analysis, net farm income and profitability ratios) were used to analyze objective ii. Multiple regression analysis was used to determine the effects of the variable inputs on the output of catfish; this was used in analyzing objective iii. Thus, combinations of statistical, budgetary and parametric techniques were used in the analysis of data collected.

\section{Model specification}

\section{Farm Budgeting (Profitability) Analysis}

The farm budgeting model used is expressed as follows as adapted by (Felipe and Adams, 2005):

N.F.I=T.R-TC

Where; N.F. I=net farm income, T.R=Total revenue ( $), T C=$ total cost $(\mathrm{N})$

$\mathrm{TR}=\mathrm{P}_{\mathrm{Y}} \cdot \mathrm{Y}_{\mathrm{I}}$

Where; $\mathrm{P}_{\mathrm{Y}}=$ unit price of output produced $(\mathrm{N}), \mathrm{Y}_{\mathrm{I}}=$ quantity of output $(\mathrm{kg})$

Total Cost $(\mathrm{TC})=\mathrm{TVC}+\mathrm{TFC}$

Where; $\mathrm{TC}=$ Total cost $(\mathrm{N}), \mathrm{TVC}=$ total variable $\operatorname{cost}(\mathrm{A}), \mathrm{TFC}=$ total fixed cost $(\mathrm{N})$

$\mathrm{TVC}=\mathrm{P}_{\mathrm{X}} \cdot \mathrm{X}_{\mathrm{I}}$

Where; $P_{X}=$ unit price of variable inputs $(\mathrm{kg} / \mathrm{liter}), \mathrm{X}_{\mathrm{I}}=$ quantity of $\mathrm{i}_{\text {th }}$ input $(\mathrm{kg} / \mathrm{liter})$

$\mathrm{TFC}=$ Total fixed cost $(\mathrm{N})$ (pond construction; pumping machine)

To determine the financial success and performance of catfish production the Benefit-cost, fixed and operating ratios were calculated. They are presented as follows: 
$\mathrm{B}-\mathrm{C}=\mathrm{TR} / \mathrm{TC}$

Where; $\mathrm{B}-\mathrm{C}=$ Benefit cost ratio, $\mathrm{TR}=$ Total returns, $\mathrm{TC}=$ Total cost

O. $\mathrm{R}=\mathrm{TVC} / \mathrm{TR}$

Where; $\mathrm{F}$. R=fixed ratio, $\mathrm{TFC}=$ total fixed cost, $\mathrm{TR}=$ total return

F. R=TFC/TR

Where; $\mathrm{O} . \mathrm{R}=$ operating ratio, $\mathrm{TVC}=$ total variable cost, $\mathrm{TR}=$ total return

Where; GM = Gross Margin ( $\mathrm{N} / \mathrm{Sqm}$.$) ; GFI = Gross Farm Income (N/Sqm.); and TVC = Total$ Variable Cost (N/Sqm.).

\section{Regression Analysis}

Multiple regression analysis was used to estimate the input and output relationship in catfish production and hence ascertain the factors influencing catfish production in the study area, a structural relationship was specified, and it showed a relationship between dependent variable (Y) and independent variables $\left(\mathrm{X}_{\mathrm{i}}\right)$. Four functional forms (linear, semi-log, double log and exponential) were specified and fitted to the data. The double-log function gave the best fit and was chosen as the lead equation. The choice of the production function is predicated on its conformation to a priori expectation in terms of signs and magnitude of the coefficients, the number of significant variables, the coefficient of multiple determination, the economic rationale, and the significance of the coefficients and the overall performance of the model and was used to analyze objective ii. The model in its explicit form is stated as follows:

$\log Y=b_{0}+b_{1} \log X_{1}+b_{2} \log X_{2}+b_{3} \log X_{3}+b_{4} \log X_{4}+b_{5} \log X_{5}+b_{6} \log X_{6}+b_{7} \log X_{7}+e_{i} \ldots \ldots$

Where;

$\mathrm{Y}=$ Catfish output $(\mathrm{kg} / 400$ square meter $(\mathrm{sqm}))$

$\mathrm{X}_{1}=\operatorname{Gender}($ male $=1$; female $=0)$

$\mathrm{X}_{2}=$ farming experience (years)

$\mathrm{X}_{3}=$ Feed $(\mathrm{kg} / 400 \mathrm{sqm})$

$\mathrm{X}_{4}=$ Stocking capacity (number of fingerlings/400 sqm)

$\mathrm{X}_{5}=$ Labour (man-days)

$\mathrm{X}_{6}=$ Size of pond $(400 \mathrm{sqm})$

$\mathrm{X}_{7}=$ Extension contact $(\mathrm{Yes}=1 ; \mathrm{No}=0)$

$\mathrm{e}_{\mathrm{i}}=$ Error term 
$\mathrm{b}_{0}=$ Intercept term showing the value of $\mathrm{Y}$ when $\mathrm{X}_{1}, \mathrm{X}_{2}, \mathrm{X}_{3}, \mathrm{X}_{4}, \mathrm{X}_{5}, \mathrm{X}_{6}, \mathrm{X}_{7}$ is zero.

The a priori expectation is that $\mathrm{X}_{1}-\mathrm{X}_{7}$ will have a positive effect on production

\section{RESULTS AND DISCUSSION}

\section{Socioeconomic Characteristics of the Respondents}

Age

Table 1: Distribution of the Respondents Based on Their Age

\begin{tabular}{lccc}
\hline Age & & Frequency & Percentage\% \\
\hline $20-39$ & 20 & 35 & 58.3 \\
$40-59$ & 33.3 & \\
60 and Above & & 5 & 8.4 \\
TOTAL & 60 & 100 & \\
\hline
\end{tabular}

Source: Field Survey, 2015

Table 1 revealed that most $(58.3 \%)$ of the respondents were within the age bracket of $20-39$ years, suggesting that most of the respondents were within their productive and economically active age brackets. According to Sikiru, et al., (2009), this age bracket is a productive age which portends a better future for catfish production.

\section{Gender}

Table 2. Distribution of Respondents Based on Their Gender

\begin{tabular}{lcc}
\hline Gender & Frequency & Percentage (\%) \\
\hline Male & 38 & 63.3 \\
Female & 22 & 36.7 \\
Total & 60 & 100 \\
\hline
\end{tabular}

Source: Field Survey, 2015

Table 2 revealed that most $(63.3 \%)$ of the respondents were male. The dominance of men in catfish production in the study area was because of the women were engaged in other economic activities like trading. Moreover, the men also have more access to productive resources. This result is in line with Esu et al (2009) who also reported that catfish production is male dominated. 


\section{Fertilization method adopted}

Table 3. Distribution of Respondents Based on the Type of Fertilization Method Adopted

\begin{tabular}{lcccc}
\hline Fertilizer type & \multicolumn{2}{c}{ Frequency } & \multicolumn{2}{c}{ Percentage (\%) } \\
\hline Organic fertilizer & 45 & 75 & \\
Inorganic fertilizer & \multicolumn{2}{c}{15} & 25 & \\
TOTAL $\quad 60$ & 100 & & \\
\hline
\end{tabular}

Source: Field Survey, 2015

The result in Table 3 revealed that most (75\%) of the respondents utilized mainly organic fertilizers. Fertilizer is an important input in catfish production. Most of the respondents claimed to have actually used poultry waste in the study area.

\section{Access to Credit}

Table 4. Distribution of Respondents Based on Their Access to Credit

\begin{tabular}{lccc}
\hline Access to Credit & & Frequency & Percentage (\%) \\
\hline Yes & 45 & 15 & 25 \\
No & 65 & 100 & \\
TOTAL & 60 & \\
\hline
\end{tabular}

Source: Field Survey, 2015

The result in Table 4 revealed that most (75\%) of the respondents had no access to credit, suggesting that the potential of the respondents to scale up their level of farm productivity is limited due to budgetary constraints.

\section{Educational Status}

Table 5. Distribution of Respondent's based on Their Educational Status

\begin{tabular}{llc}
\hline Educational Status & Frequency & Percentage (\%) \\
\hline No formal education & 15 & 25 \\
Formal education & 45 & 75 \\
\hline
\end{tabular}

Source: Field Survey, 2015

The result in Table 5 revealed that most (75\%) of the respondents had attained various levels of education, suggesting that the respondents were functionally literate. With this distribution, it will be convenient for most catfish farmers in this area to understand modern management practices in the enterprise and also easily adopt new innovations and technology introduced by 
the State Agricultural Extension Agents (such as new improved fingerlings, feed formulation, water management strategy, etc.).

\section{Management system}

Table 6. Distribution of Respondents Based on Their Management System

\begin{tabular}{lcc}
\hline Pond type & Frequency & Percentage (\%) \\
\hline Earthen & 50 & 83.3 \\
Concrete & 10 & 16.7 \\
Total & 60 & 100 \\
\hline
\end{tabular}

Source: Field Survey, 2015

The result in Table 6 revealed that most $(83.3 \%)$ of the respondents used earthen ponds as their management system. This result is in line with Asaet al., (2012) whom also posited that most catfish farmers in the Niger delta region use earthen ponds for catfish production.

\section{Marital Status}

Table 7. Distribution of Respondents Based on Their Marital Status

\begin{tabular}{lcc}
\hline Marital status & Frequency $(\mathrm{F})$ & Percentage (\%) \\
\hline Married & 50 & 83.3 \\
Single & 10 & 16.7 \\
Total & 60 & 100 \\
\hline
\end{tabular}

Source: Field Survey, 2015

The result in Table 7 revealed that most $(83.3 \%)$ of the respondents were married.Asaet al., (2012) noted that marriage is a highly cherished social value among fish farmers in the Niger delta region and this result corroborates that.

\section{Household Size}

Table 8. Distribution of Respondents Based on Their Household Size

\begin{tabular}{lcc}
\hline Household Size & Frequency & Percentage (\%) \\
\hline $1-5$ & 35 & 58.3 \\
$6-10$ & 15 & 25 \\
11 and above & 10 & 16.7 \\
Total & 60 & 100 \\
\hline
\end{tabular}

Source: Field Survey, 2015 
The result in Table 8 revealed that most $(58.3 \%)$ of the respondents had a household size with a population of 1-5 people. These household sizecan provide adequate family labour supply for catfish production to most of the respondents if and when needed. This suggests an adequacy of family labour supply required to carry out catfish farming operations. This result agrees with Adebayo (2012) who also posited that householdpopulation can serve as source farm labour supply.

\section{Farming Experience}

Table 9. Distribution of Respondents Based on Their Farming Experience

\begin{tabular}{lcc}
\hline Farming Experience & Frequency & Percentage (\%) \\
\hline $1-5$ & 40 & 66.7 \\
$6-10$ & 15 & 25 \\
11 and above & 5 & 8.3 \\
Total & 60 & 100 \\
\hline
\end{tabular}

Source: Field Survey, 2015

The result in Table 9 revealed that most $(66.7 \%)$ of the respondentshave been involved in catfish farming for 1-5 years. This may be attributable to the fact that commercial catfish production is a relatively new idea in the study area. This result is in line with Wurts (2004), who also posited that the ability to manage fish ponds efficiently depends on the years of farming experience and this has a direct correlation with the level of farm productivity.

\section{Farm Labour Supply}

Table 10. Distribution of respondents based on the type of labour employed

\begin{tabular}{lcc}
\hline Type of labour & Frequency & Percentage (\%) \\
\hline Hired labour & 45 & 75 \\
Family labour & 15 & 25 \\
Total & 60 & 100 \\
\hline
\end{tabular}

Source: Field Survey, 2015

The result in Table 10 revealed that most $(75 \%)$ of the respondents employed hired labour on their farms for their catfish production activities, suggesting an increased production cost component in their farm activity. 


\section{Access to Extension}

Table 11. Distribution of Respondents Based on Their Access to Extension Contact

\begin{tabular}{lcc}
\hline Access to extension & Frequency & Percentage (\%) \\
\hline Yes & 5 & 8.3 \\
No & 55 & 91.7 \\
Total & 60 & 100 \\
\hline
\end{tabular}

Source: Field Survey, 2015

The result in Table 11 revealed that most $(91.7 \%)$ of the respondents had no extension contact, suggesting that extension activities in the study area especially with catfish farmers were grossly inadequate.

\section{Pond Size}

Table 12. Distribution of Respondents Based on Their Pond Size

\begin{tabular}{lccc}
\hline Pond size (sqm) & Frequency (F) & Percentage (\%) \\
\hline $1-400$ & 35 & 58.3 \\
$401-800$ & 15 & 25 \\
$801-1200$ & 10 & 16.7 & \\
Total & 60 & 100 & \\
\hline
\end{tabular}

Source: Field Survey, 2015

The result in Table 12 revealed that most (58.3\%) of the respondents had pond sizes within the range of 1-400 sqm. Theywere variations in the pond sizes of the respondents. The average pond size in the study area was 482 square meter, with an average depth of 3 meters. This conforms to theFAO, 2007submission that ponds as small as 1-400 sqm range are suitable. However, ponds in the 401-800 sqm range are more practical.

\section{Stocking capacity of catfish seeds (fingerlings)}

Table 13. Distribution of the Respondents Based on Their Stocking Capacity

\begin{tabular}{llc}
\hline Stocking capacity & Frequency $(F)$ & Percentage (\%) \\
\hline$\leq 1000$ & 20 & 33.3 \\
$1001-2000$ & 35 & 58.3 \\
2001 and above & 5 & 8.4 \\
\hline
\end{tabular}

Source: Field survey, 2015 
The result in Table 13 revealed that most $(58.3 \%)$ of the respondents had a stocking capacity of 1001-2000 fingerlings. This is not unconnected to their pond sizes, so as to ensure optimum stocking density for their catfish production. However, the average stocking rate for the respondents in the study area was 1200 fingerlings.

\section{Cost and Returns Analysis}

According to the respondents, harvesting is carried out twice in a year, i.e., at six (6) months interval. The following analysis is done based on one production cycle $(1000 \mathrm{~kg})$ for $400 \mathrm{sqm}$ pond size in the study area.

Table 14. Cost and Returns Analysis of Catfish Production per Production Cycle

\begin{tabular}{llc}
\hline Variables & Cost (N/1000kg) & Percentage (\%) \\
\hline 1. Variable cost: & 250,000 & 38.6 \\
\hline Catfish feeds & 7,000 & 1.08 \\
\hline Fertilizer & 6,000 & 0.93 \\
\hline Liming & 54,000 & 8.35 \\
\hline Labour & 50,000 & 7.73 \\
Catfish seeds(fingerlings) & 367,000 & \\
\hline Total variable cost(TVC) & 56.7 & 38.6 \\
\hline 2.Fixed cost: & & 4.7 \\
\hline Pond construction & 250,000 & \\
\hline Pumping machine & 30,000 & \\
\hline Total fixed cost(TFC) & 280,000 & \\
\hline Total cost(TVC+TFC) & 647,000 & \\
\hline 3.Total Revenue(TR) & $1,080,000$ & \\
\hline 4.Net farm income(TR-TC)433,000 & & \\
\hline 5.Benefit cost ratio(TR/TC) & 1.67 & \\
\hline 6.Operating ratio (TVC/TR) & 0.67 & \\
\hline 10.Fixed ratio(TFC/TR) & 0.43 & \\
\hline Soure: Field Survey, 2015 & \\
\hline
\end{tabular}

Source: Field Survey, 2015

The profitability of catfish production is estimated using costs and returns analysis. The result in Table 14 revealed that fixed cost constituted $43.3 \%$ of the total cost of catfish production while the variable cost constituted 56.7\%. The cost of catfish feeds $\$ 250,000$ and earthen pond 
construction $\$ 250,000$ constituted the most significant production cost of the respondents at $38.6 \%$ respectively. The average output of catfish per production cycle was $900 \mathrm{~kg}$ from a 400 sqm pond size. The average price per $1 \mathrm{~kg}$ of catfish is 1200.00 . The result also revealed that the total production cost of catfish was $¥ 647,000$, while the total revenue accruable was 080,000 from the sales of the harvested catfish, hence the estimate of net farm income was 433 , 000, suggesting that catfish production in the study area was a relatively profitable venture with proper management. This result is in line with Asa et al., (2012) who also reported that fish production was a viable venture. Ohen and Abang (2009) also reported that catfish farming is profitable venture in Rivers State, Nigeria.

\section{Profitability Ratio Estimates}

The result in Table 14 also revealed the estimates of profitability ratios. The estimate of Benefit cost ratio (BCR) was 1.67, suggesting that catfish production was a relatively profitable venture. The value (1.67) simply means that every 1.00 invested in catfish enterprise will yield 1.67 . This ratio is one of the concepts of discount method of project evaluation. As a rule of thumb, project with benefit cost ratio greater than one, equal to one or less than one indicate profit, break-even or loss respectively. Hence the profitability index was estimated to be greater than one (1.67, therefore P.I>1) it indicates profit and suggests that the enterprise is a viable venture. It is therefore possible to have higher value of BCR with increased investments.Also, the fixed and operating ratios were 0.43 and 0.67 respectively, implying that catfish production in the study area was relatively profitable. Hence, catfish production in the study area is a very viable farm enterprise that has the capacity to improve the living standards of the rural farmers.

\section{Regression analysis}

Table 15. Factors Influencing Catfish Production in the study area

\begin{tabular}{lccc}
\hline Variable & Coefficients & Standard Error & T-value \\
\hline Constant & $5.541^{* * *}$ & 1.346 & 4.116 \\
Gender $\left(\mathrm{X}_{1}\right)$ & $0.842^{\mathrm{ns}} 0.836$ & \multicolumn{1}{c}{1.007} & \\
Farm experience $\left(\mathrm{X}_{2}\right)$ & $0.504^{* *}$ & 0.1962 .571 & 4.194 \\
Feed $\left(\mathrm{X}_{3}\right)$ & $3.020^{* * *}$ & 0.720 & -4.178 \\
Stocking capacity $\left(\mathrm{X}_{4}\right)$ & $-0.635^{* * *}$ & 0.152 & 2.747 \\
Labour $\left(\mathrm{X}_{5}\right)$ & $0.489^{* *}$ & 0.178 & -0.875 \\
Pond size $\left(\mathrm{X}_{6}\right)$ & $-0.364^{\mathrm{ns}}$ & 0.875 & 2.721 \\
Extension contact $\left(\mathrm{X}_{7}\right)$ & $0.536^{* *}$ & 0.197 & \\
$\mathrm{R}^{2}$ & 0.839 & & \\
F-value & 26.11 & & \\
\hline Source: Field & & & \\
\hline
\end{tabular}

Source: Field survey, 2015; $* * *$, $* *=$ significant at $1 \%$ and 5\%levels respectively; ${ }^{\text {n.s }}=$ not significant

The regression analysis presented in Table 15 revealed the factors influencing catfish production in the study area. The estimated coefficient of determination $\left(\mathrm{R}^{2}\right)$ was 0.839 implying that $84 \%$ of 
the variation in the output of catfish measured in kilograms were explained by the independent variables in the regression model, while the remaining $16 \%$ are exogenous to the system, i.e. unexplained and attributable to the random stochastic error term $\left(\mathrm{e}_{\mathrm{i}}\right)$. The coefficient of farming experience (0.504) was positive and statistically significant $5 \%$ level of significance. It could be deduced that the younger farmers were more productive than the older ones in the area of study.In addition, the coefficient of feed quantity (3.020) was positive and statistically significant $1 \%$ level of significance, implying that as feed increases, gross output of catfish also increases and thus holds true that feed is a very important variable in relation to catfish output. Feed therefore was discovered to be an essential production input. Also, the coefficient of stocking capacity (-0.635) was negative and statistically significant $1 \%$ level of significance. This implied that higher stocking capacities lead to reduced output as the space occupied by each catfish in terms of water volume is reduced. Cannibalism becomes frequent and struggle for feed is increased. This results in high mortality rate and thus has an adverse effect on output. Furthermore, the coefficient of labour (0.489) was positive and statistically significant $5 \%$ level of significance, suggesting that labour supply is a key component of catfish production hence it is major requirement for carrying out the various farm operations. The coefficient of extension contact (0.536) was positive and statistically significant $5 \%$ level of significance, suggesting that as the respondents had more access to extension contact they will have a higher likelihood of adopting improved production technologies and henceincrease their level of gross output,ceteris paribus.

\section{Constraints Associated with Catfish Production}

Table 16. Distribution of Respondents Based on the constraints of catfish production

\begin{tabular}{lcccc}
\hline Constraints & \multicolumn{2}{c}{ Frequency (F) } & Percentage (\%) \\
\hline 1. Inadequate capital & 55 & & 91.7 & 83.3 \\
2. High cost of feed & 55 & & 41.7 & \\
3. Fish mortality & 20 & & 33.3 & \\
4. Water pollutants & & 45 & & \\
5. High cost of pond construction & & 30 & & 75 \\
6. High labour cost & & 58.3 & 50 \\
7. Poor access to modern technologies35 & 10 & & 16.7 \\
8. Inadequate extension contact & & 15 & & 25 \\
9. Poor market linkages & & 40 & & 66.7 \\
10.Scarcity of seeds (Fingerlings) & &
\end{tabular}

Source: Field Survey, 2015;*=multiple responses recorded

The result in Table 16 revealed the mostprevalent constraints of catfish production in the study area were; high cost of feeds (91.7\%), the result corroborates with Ohen and Abang (2009) who reported that high cost of feeds is a major constraint to catfish farming in Nigeria.Inadequate capital (83.3\%), the result corroborates with Kudi et al (2008) who also reported that inadequate capital was a major production constraint, also Sikiru et al (2010) identified inadequate finance 
as a serious problem in catfish production.High cost of pond construction (75\%); the respondents revealed that catfish farming requires a huge initial capital outlay especially for pond construction, catfish farming requires a huge capital outlay especially for pond construction, this results corroborates with Ohen and Abang (2009) and Kudi et al (2008). Seed (fingerling) scarcity (66.7\%), poor access to improved production technology (58.3\%), high labour cost (50\%), fish mortality (41.7\%), water pollutants (33.3\%), poor market linkages (25\%) and inadequate extension contact $(16.7 \%)$. Furthermore, this results are in consonance with the findings of Ugwumba and Nnabuife (2008) and Olasunkanmi and Yususf (2013).

\section{CONCLUSION AND RECOMMENDATIONS}

\section{Conclusion}

The study revealed that the socioeconomic factors of the respondents affected their farm productivity. Moreover, catfish production in the study area was relatively profitable. Furthermore, the variables in the regression model significantly affected catfish production and were determinants of the level of farm productivity and consequent profitability. All the constraints identified affected the catfish production in the study area. Based on the findings of this study, the following recommendations are hereby made to boost catfish production in the study area:

i. It is recommended that prices of feeds and access to feeds by catfish farmers be regulated by the Government in order to ameliorate the problems of high cost of feeds/inadequate supply of feeds to catfish farmers.

ii. Effort should be made to bring down the cost of feeds by exploring alternative sources of feeds for catfish through well-funded researches.

iii. The Government should also subsidize the cost of feeds and other production inputs in order to reduce the cost of catfish production. This will encourage more farmers to be engaged in commercial catfish production.

iv. Catfish farmers should explore available credit opportunities within their community to avail themselves capital required to expand their scale of production.

v. Government could formulate policies that will further improve farmers access to agricultural credit this may include; Agricultural Credit Guaranteed Scheme Fund which enhanced credit availability to the farmers and taking care of tangible proportion of any default so as to encourage the commercial banks to make credit facilities available to farmers.

vi. Catfish farmers should come together to form cooperatives or unions that will enable them pool their resources together so as to boost their level of productivity andincrease their economies of scale.

vii. Adequate trainings and seminars should be organized at regular intervals to update catfish farmers' knowledge on current production trends, so as to enhance their access to improved methods, technologies and create market linkages.

viii. Government should provide incentives and improve access to production inputs (fingerlings, technology, etc.). 
ix. The catfish farmers in the study area could improve their farm productivity by adopting improved production practices and technological innovations.

x. Formulation of policies that will regulate labour costs in order for the fish farmers to obtain output optimization, as well as cut cost of production to further increase level of profitability. 


\section{REFERENCES}

Adebayo, O.O. (2012). Determinants of Extension Service Needs Of catfish Farmers in Oyo State, Nigeria: A case Study of Ido Local Government Area. J. Humanities and Soc. Sci. 1(4):54-58.

Amao, J. O., Awoyeni, T. T., Omonona, B. T. and Falusi, A. O. (2009). Determinants of poverty among fish farming households in Osun State, Nigeria, International Journal of Agricultural Economics and Rural Development, 2 (2): 14-25.

Asa, U.A. and Obinaju, L.C. (2014). Economics of catfish production in Akwalbom State, Nigeria. Global Journal of Management and Business Research; 14(3): 23-7.

Asa, U.A., Uwem, C.A. and Ukpong, U.N. (2012). Economics of fish farming in AkwaIbom State, Nigeria. Agricultural Economics and Extension Research Studies; 1(2); 77-81.

Dada, R.V. (2004). Profitability of Artisanal Fish Farming in Badagry Local Government Area of Lagos State. B.Tech Thesis, Unpublished. LadokeAkintola University of Technology, Ogbomoso, Oyo State, Nigeria.

Emokaro, C.O., Ekunwe, P.A. and Achille, A. (2010). Profitability and viability of catfish farming in Kogi State, Nigeria. J. Agric. Biol. Sci. 6 (3):215-219.

Esu, B.B., Asa, U.A. and Iniedu, M.O. (2009). Costs and returns of fish production using earthen ponds in Akwa Ibom State, Nigeria. Nigerian Journal of Agriculture, Food and Environment 2009; 5(2): 26-29.

Felipe, J. and Adams, F.G. (2005). The estimation of the Cobb-Douglas function: a retrospective view. Eastern Economic Journal 2005; 31(3): 427-445.

Food and Agriculture Organization (FAO) (2007). State of World Fisheries \& Aquaculture http://www.fao.org/fi/statist/fisoft/fishplu.asp.

Food and Agriculture Organization (2006). Yearbook of fisheries statistics and summary table; 2006 [cited 2011 Nov 20]: Available from: http://www.fao.org/fi/statist.asp

Food and Agriculture Organization (FAO) (1999). FAO Yearbook fisheries statistics: Aquaculture production. Vol. 86/2. FAO Fish Ser. No. 56.

En.m.wikipedia.org/wiki/Ekeremor, 2015. Retrieved 3 ${ }^{\text {rd }}$ August, 2015

Kudi, T. M., Bako, F. P. and Atala, T. K. (2008). Economics of fish production in Kaduna State, Nigeria, ARPN Journal of Agricultural and Biological Science, 3 (5 and 6): 17-21.

Ocmer, R. (2006). Raising and Production of Catfish. Retrieved from: http://www.mixph.com/2006/06/raising-and- production-of-catfishhito- html

Oguntola, S. (2001). How to achieve profitable fish farming in Nigeria; 2001: February 20, 
Nigerian Tribune Newspaper.

Ohen, S. B. and Abang, S. O. (2009). Economics of catfish farming in Rivers State, Nigeria, Academic Journal of Plant Sciences, 2(1): 56-59.

Okechi, J.K. (2004). Profitability assessment: a case study of African catfish (Clariasgariepinus) farming in the Lake Victoria Basin, Kenya. Fisheries Training Programme. Iceland: The United Nations.

Okwu, O.J. and Acheje, S. (2011). Socio-Economic Analysis of Fish Farming in Makurdi Local Government Area, Benue State, Nigeria .Eur. J. Social Sc. 23(4).

Olagunju, F.I., Adeyisan, I.O. and Ezekiel, A.A. (2007). Economic viability of catfish production in Oyo State, Nigeria. J Hum Ecol.; 21(2): 121-124.

Olasunkanmi, N.O. and Yusuf, O. (2013). Resource use efficiency in small scale catfish farming in Osun State, Nigeria. Sky Journal of Agricultural Research; (1): 37-45.

Ugwumba, C.O.A. and Chukwuji, C.O. (2010). The economics of catfish production in Anambra State, Nigeria: a profit function approach. J AgricSocSci; 6: 105-109.

Ugwumba, C.O.A. and Nnabuife, E.L.C. (2008). Comparative Study on the Utilization of Commercial Feed and Home-made Feed in Catfish Production for Sustainable Aquaculture. Multidiscipl.J. Res. Dev., 10: 164-169

Sikiru, B.O., Omobolanle, N.M., Ayorinde, B.J.O. and Adegoke, O.O. (2009). Improving Clarias productivity. J. Biol. Res. 3(1- 2):24-28.

Wurts, W.A. (2004). Small-scale and home use channel catfish farming in Kentucky. World Aquaculture; 35(3): 8-9. 